\title{
Pengaruh Model Pembelajaran Team Assisted Individualization (TAI) Berbatuan Video Interaktif dalam Pembelajaran Jarak Jauh terhadap Kemampuan Pemecahan Masalah Matematis Siswa SMP Negeri 172 Jakarta
}

\author{
Marisa Fisabti Fadlilah", a), Swida Purwanto ${ }^{2, \text { b) }}$, Lukman El Hakim³, c) \\ ${ }^{123}$ Universitas Negeri Jakarta
}

Email: a)marisafisabti_3115160611@mhs.unj.ac.id, b)

\begin{abstract}
Abstrak
Tujuan dilakukannya penelitian ini adalah untuk mengetahui apakah ada atau tidaknya pengaruh model pembelajaran Team Assisted Individualization berbantuan video interaktif dalam pembelajaran jarak jauh terhadap kemampuan pemecahan masalah matematis siswa. Metode eksperimen semu digunakan sebagai metode dalam penelitian ini. Populasi target pada penelitian ini adalah seluruh siswa SMPN 172 Jakarta, sedangkan populasi terjangkaunya adalah seluruh siswa kelas VIII. Cara pengambilan sampel menggunakan teknik purposive random sampling dan cluster random sampling. Instumen tes kemampuan pemecahan masalah matematis yang digunakan dalam penilitian ini berupa 4 butir soal uraian yang telah dinyatakan valid. Berdasarkan hasil prasyarat analisis data setelah perlakuan, kelas kontrol dan kelas eksperimen masing-masing homogen dan berdistribusi normal. Merujuk pada hal tersebut maka dilakukanlah uji t untuk pengujian hipotesis dengan taraf signifikansi $\alpha=0,05$. Perolehan hasil perhitungan hipotesis statistik memberi kesimpulan bahwa rata-rata kemampuan pemecahan masalah matematis kelas eksperimen lebih tinggi daripada kelas kontrol. Hal tersebut menunjukkan bahwa terdapat pengaruh model pembelajaran TAI berbantuan video interaktif dalam pembelajaran jarak jauh terhadap kemampuan pemecahan masalah matematis siswa SMP Negeri 172 Jakarta. Besar pengaruh yang diberikan adalah $79 \%$ dan termasuk dalam kategori tinggi.
\end{abstract}

Kata kunci: team assisted individualization (TAI), kemampuan pemecahan masalah matematis, video interaktif.

\section{PENDAHULUAN}

Matematika merupakan elemen yang dapat memengaruhi kemajuan teknologi dan ilmu pengetahuan. Susanto (2016) mengemukakan bahwa matematika adalah ilmu dasar yang mampu mengembangkan kecakapan berpikir dan beragumentasi sehingga dapat memberikan kontribusi untuk menyelesaikan masalah di kehidupan nyata dan pada lingkungan kerja, dan dapat berperan penting dalam kemajuan teknologi dan ilmu pengetahuan. Dengan demikian, pembelajaran matematika penting untuk membekali dan membentuk siswa agar terampil berpikir sistematis, kreatif, analitis, kritis, dan logis.

Menurut The National Council of Teachers of Mathematics (NCTM) dalam Purwaningsih (2017), kecakapan dasar matematika yang mesti diraih siswa dalam pembelajaran ada lima, yaitu kemampuan representasi, kemampuan menyelesaikan masalah, kemampuan koneksi, kemampuan komunikasi, dan kemampuan penalaran. Menurut Sumarmo (2005), dalam pembelajarannya kemampuan-kemampuan matematika tersebut dapat berguna sebagai pemenuhan kebutuhan siswa saat ini ataupun yang akan 
datang. Kebutuhan siswa saat ini, yaitu siswa dapat mengerti konsep-konsep penting dalam menyelesaikan masalah matematis maupun ilmu pengetahuan lainnya ketika masih sekolah, sedangkan kebutuhan siswa yang akan datang yaitu menguasai kemampuan penalaran yang diperlukan untuk bersaing dengan negara lain. Dengan demikian, pembelajaran matematika dalam kelas harus diperhatikan agar tujuan tersebut tercapai. Kemampuan pokok dalam proses pembelajaran matematika yang mesti dicapai ialah kemampuan pemecahan masalah matematis.

Kemampuan pemecahan masalah matematis ialah kecakapan menentukan strategi dalam menerapkan konsep matematis yang dipahami untuk memecahkan masalah atau situasi yang tidak rutin. Widjajanti (2009) menyatakan bahwa pemecahan masalah matematis akan melatih ketekunan, proses berpikir siswa, dan kepercayaan diri, serta keingintahuan di dalam berbagai situasi baru yang akan mereka hadapi di kehidupan nyata. Dengan demikian, dalam kegiatan pembelajaran matematika harus mementingkan pemecahan masalah karena dengan kemampuan tersebut dapat melatih kemampuan berpikir, keingintahuan, dan kepercayaan diri sehingga ketika siswa menghadapi masalah di kehidupan nyata sehari-hari mereka akan mudah menyelesaikannya.

Fakta di lapangan menunjukkan bahwa kemampuan pemecahan masalah matematis masih tergolong rendah. Hasil tes yang diselenggarakan oleh TIMSS 2015 menujukkan bahwa Indonesia berada pada peringkat 45 dari 50 negara yang ikut serta dengan nilai rata-rata 397. Diperoleh hasil penelitian Bernard, dkk (2018) yang menyimpulkan persentase kemampuan pemecahan masalah matematis dalam memahami permasalahan, merancang penyelesaian, menerapkan sesuai rencana yang dibuat dalam menyelesaikan masalah, dan melakukan pengecekan ulang masuk dalam kategori rendah, yakni $53 \%$.

Fakta lain ditunjukkan oleh hasil uji kemampuan pemecahan masalah yang dilakukan di sekolah SMPN 172 Jakarta. Perolehan hasil tes menujukkan nilai rata-rata siswa dalam menjawab dan memecahkan soal pemecahan masalah adalah 36,74. Dari hasil tersebut terdapat 30\% dari siswa masuk ke dalam kategori sangat kurang, 40\% memperoleh nilai yang termasuk dalam kategori kurang, $21 \%$ dari siswa termasuk pada kategori cukup, dan hanya 9\% dari siswa mendapat kategori baik. Hasil tes awal kemampuan pemecahan masalah menunjukkan kategori sangant kurang dan kurang lebih mendominasi daripada kategori cukup dan baik.

Penyebab dari rendahnya kemampuan pemecahan masalah matematis ialah penerapan pemebelajaran matematika konvensional dimana yang menjadi pusat pembelajaran adalah guru. Pembelajaran yang masih berpusat pada guru membuat kondisi belajar cenderung monoton, membosankan, dan siswa menjadi pasif. Di sisi lain, saat ini di Indonesia sedang diterapkan pembelajaran jarak jauh akibat mewabahnya coronavirus atau yang biasa disebut COVID-19. WHO sudah menetapkan penyebaran virus ini sebagai kedaruratan kesehatan yang meresahkan masyarakat. Untuk mengurangi penyebaran kasus COVID-19 pemerintah mengeluarkan kebijakan untuk menunda sementara semua kegiatan di luar maupun di dalam ruangan pada semua sektor agar tidak terjadi kerumunan. Kebijakan pada sektor pendidikan ketika masa COVID-19 yaitu proses kegiatan pembelajaran menerapkan pembelajaran daring/jarak jauh yang dilakukan dari rumah masing-masing.

Ahmad (2020) mengatakan bahwa PJJ merupakan proses kegiatan belajar mengajar, akan tetapi keberadaan guru dan siswa tidak dalam satu kelas melainkan dalam tempat yang terpisah dan berbeda saat pembelajaran berlangsung. Pembelajaran jarak jauh juga melibatkan media elektronik sebagai sarana dalam penyampaian materi kepada siswa. Pakpahan dan Fitriani (2020) mengemukakan bahwa perlu adanya pemanfaatan teknologi informasi untuk menunjang pelaksanaan PJJ dengan menerapkan perangkat komputer atau gawai yang menghubungkan siswa dan guru.

Aturan diberlakukannya pembelajaran jarak jauh guna menurunkan resiko tersebarnya coronavirus yang dilakukan secara tidak terduga membuat kurangnya persiapan dalam kegiatan belajar dan mengajar. Setiawan dan Mufassaroh (2020) mengemukakan bahwa tahap awal penerapan PJJ di Kabupaten Kudus, guru dan siswa memerlukan upaya lebih untuk menyesuaikan diri dengan media pembelajaran yang digunakan daripada kegiatan pembelajaran dan mengalami kesulitan dalam disiplin diri dan manajemen waktu sehingga tidak ada sisi interaksi langsung selama pembelajaran. Pembelajaran matematika konvensional ditambah dalam kondisi pembelajaran jarak jauh dapat memengaruhi keaktifan dan kreativitas siswa dalam penyelesaian masalah matematis. 
Pengembangan kemampuan pemecahan masalah matematis dalam PJJ dapat didukung melalui penerapan model pembelajaran yang berpedoman pada pemahaman matematika yang aktif dan kreatif serta memberikan kesempatan dan meningkatkan minat siswa untuk mengeksplor, mengemukakan pendapatnya serta bertukar pikiran dengan teman yang lain. Sumartini (2016) mengatakan bahwa jika pembelajaran yang dipilih sudah tepat untuk mencapai tujuan belajar maka dapat mendukung peningkatan kemampuan pemecahan masalah. Salah satu model pembelajaran yang dapat diterapkan adalah model TAI. Hal tersebut sejalan dengan penelitian Achdiyat \& Andriyani (2016) mengemukakan bahwa kegiatan pembelajaran yang menggunakan model pembelajaran TAI mampu meningkatkan hasil belajar matematika siswa.

Inayatusufi, El Hakim, dan Sari (2020) mengatakan bahwa pembelajaran kooperatif mengharuskan siswa untuk berpikir aktif, menyelesaikan permasalahan secara berkelompok, dan siswa diberi keleluasaan untuk saling berinteraksi sehinga dapat diterapkan untuk mengurangi masalah yang dihadapi siswa. Widodo (2015) menyatakan bahwa model pembelajaran TAI ialah jenis pembelajaran kooperatif yang disusun untuk memberikan bantuan secara individu di dalam kelompok. Dari hasil belajar mandirinya, siswa berkelompok untuk mengemukakan ide-ide dan gagasannya serta berdiskusi bersama dalam menyelesaikan masalah dan memberikan dorongan kepada anggota kelompoknya yang lain untuk selalu berusaha sampai berhasil.

Media pembelajaran juga berpengaruh terhadap proses pembelajaran. Alternatif media pembelajaran yang efektif guna meningkatkan semangat dan memudahkan siswa dalam belajar adalah video interaktif. Dalam pengembangannya, kini sudah banyak adanya berbagai jenis aplikasi sebagai media yang berguna untuk menampilkan video dan berinteaksi langsung secara virtual dalam pembelajaran jarak jauh, salah satunya adalah Google Meet. Penggunaan video interaktif dalam pembelajaran jarak jauh dapat memudahkan siswa untuk memahami konsep materi yang diajarkan daripada hanya sekadar membaca. Mahadewi, Ardana, \& Mertasari, (2020) menyatakan bahwa adanya perbedaan kemampuan pemahaman siswa dalam pembelajaran dapat diatasi dengan digunakannya media interaktif berupa video pembelajaran sehingga siswa yang tidak paham dengan hanya membaca dapat terbantu.

Penerapan model pembelajaran TAI berbantuan video interaktif dalam proses kegiatan belajar dan mengajar matematika yang dilakukan secara daring/jarak jauh memberikan pembelajaran yang lebih bermakna karena mengikutsertakan siswa dalam pelaksanaan pembelajaran agar mengaktifkan siswa dan membantu siswa memahami materi pelajaran sehingga memudahkan siswa menemukan solusi untuk menyelesaikan masalah. Berdasarkan uraian yang telah dipaparkan maka penelitian ini dilakukan untuk mengetahui apakah model pembelajaran Team Assisted Individualization (TAI) berbatuan video interaktif dalam pembelajaran jarak jauh dapat berpengaruh terhadap kemampuan pemecahan masalah matematis siswa.

\section{Kemampuan Pemecahan Masalah Matematis}

Widjajanti (2009) mendefinisikan masalah sebagai situasi yang sulit bagi seseorang, menantang dan prosedur untuk menyelesaikan masalah tersebut tidak dapat dilakukan secara rutin. Dapat dikatakan masalah matematis merupakan masalah yang bersangkutan dengan matematika. Masalah matematis menurut Yunata (2017) adalah penyelesaian suatu pertanyaan dengan algoritma yang tidak rutin serta menggunakan konsep dan ide-ide matematika. Disisi lain, Hendriana \& Soemarmo (2014) mengemukakan bahwa masalah matematis merupakan suatu tugas matematis yang penyelesaiannya harus melalui beberapa kegiatan yang relevan sehingga tidak dapat diperoleh secara langsung. Jadi, dapat dikatakan bahwa masalah matematis merupakan suatu tugas, pertanyaan, atau kondisi yang memerlukan pemecahan masalah matematika yang melalui kegiatan lain yang relevan dan tidak dapat diketahui solusi maupun cara memecahkannya secara langsung.

Pemecahan masalah merupakan proses yang dapat diterapkan dalam penyelesaian kondisi tertentu. Pemecahan masalah menurut Suprika (2014) adalah upaya strategis yang menerapkan keterampilan dan konsep dalam mengidentifikasi masalah, pemilihan strategi pada penyelesaian masalah, dan menyelesaikan permasalahan. Aisyah (2011) mengemukakan bahwa maksud dari pemecahan masalah dalam matematika adalah penerapan berbagai prinsip, konsep, dan kompetensi matematika yang 
sedang atau sudah dipelajari untuk menyelesaikan masalah yang sebelumnya belum diketahui. Berdasarkan uraian yang telah dipaparkan, pemecahan masalah dapat dinyatakan sebagai sebuah proses atau upaya guna menyelesaikan masalah baru yang belum dikenalnya dan memerlukan proses dengan menerapkan pemahaman yang diketahui sebelumnya serta menggunakan keterampilan, konsep, prinsip matematis yang sedang atau telah dipelajari.

Kemampuan pemecahan masalah matematis mesti dimiliki setiap siswa. NCTM menjelaskan tujuan dari pengajaran pemecahan masalah antara lain untuk membentuk pemahaman matematika baru, menyelesaikan masalah dalam konteks matematika maupun dalam hal yang lain, menyesuaikan dan menerapkan strategi penyelesaian yang cocok untuk menyelesaikan permasalahan, serta merefleksikan dan memeriksa proses dari penyelesaian masalah matematika. Sundayana (2016) mengatakan bahwa satu diantara beberapa tujuan dalam pembelajaran matematika ialah kemampuann pemecahan masalah yang berguna untuk mengasah kecakapan siswa dalam memilih informasi yang relevan, menganalisis, dan mengevaluasi hasilnya. Berdasarkan uraian tersebut, maka pentingnya kemampuan pemecahan masalah dalam pencapaian tujuan umum pembelajaran matematika.

Untuk mendapatkan keterangan mengenai kemampuan pemecahan masalah, maka dibutuhkan adanya indikator kemampuan pemecahan masalah. Beberapa para ahli merumuskan indikator kemampuan pemecahan masalah dengan rincian yang hampir sama. Sumarmo (2010) menyebutkan indikator yang harus diperhatikan dalam pemecahan masalah, antara lain adalah (1) Menyebutkan kecukupan data yang diperlukan, hal-hal yang diketahui dan ditanya, (2) Menafsirkan masalah dari situasi atau membentuk model matematika, (3) Memecahkan masalah terkait matematika atau terkait hal lain dengan memilih dan mengaplikasikan strategi, (4) Menginterpretasikan dan menjelaskan hasil penyelesaian berdasarkan permasalahan sebelumnya, (5) Menggunakan matematika secara relevan.

Indikator kemampuan pemecahan masalah matematis menurut NCTM (National Council of Teachers of Mathematics) (2003), yaitu (a) Mengadaptasi serta menggunakan berbagai pendekatan dan strategi untuk memecahkan permasalahan, (b) Memecahkan permasalahan yang ada, baik yang bersangkutan dengan matematika maupun hal lain yang terkait matematika, (c) Membentuk pengetahuan matematis yang baru melalui penyelesaian masalah, (d) Melihat kembali dan mengoreksi pada proses pemecahan masalah matematis. Adapun Lestari dan Yudhanegara (2015) menyebutkan bahwa indikator kemampuan pemecahan masalah matematis, yaitu mengidentifikasi unsur-unsur yang diketahui, ditanyakan, serta kecukupan unsur yang diperlukan; merumuskan masalah matematis atau menyusun model matematis; menerapkan startegi untuk pemecahan masalah; dan menjelaskan atau menginterpretasikan hasil penyelesaian masalah.

Berdasarkan uraian dari berbagai pendapat ahli yang dijelaskan sebelumnya, maka dapat disimpulkan bahwa kemampuan pemecahan masalah matematis ialah kecakapan memilih strategi dalam menerapkan konsep, prinsip, dan keterampilan matematika yang siswa miliki sebelumnya untuk menyelesaikan masalah atau situasi tidak rutin dengan proses yang panjang. Tahap penyelesaian masalah dalam penelitian ini mengacu pada langkah Polya, yaitu understanding the problem, devising a plan, carrying out the plan, dan looking back. Adapun indikator kemampuan pemecahan masalah dalam penelitian ini merupakan gabungan dari beberapa pendapat ahli, diantaranya adalah (1) Memahami masalah dengan mengidentifikasi unsur-unsur yang diperlukan, seperti diketahui dan ditanyakan serta syarat yang diperlukan dalam menyelesaikan masalah, (2) Merancang dan menyusun strategi penyelesaian masalah, merumuskan masalah matematis atau menyusun model matematika, (3) Menerapkan rencan strategi untuk memecahkan masalah dalam konteks matematika, (d) Memeriksa kembali hasil yang diperoleh dan menginterpretasikannya.

\section{Model Pembelajaran Team Assisted Individualization (TAI)}

Model pembelajaran TAI merupakan salah satu model pembelajaran kooperatif. Slavin merupakan orang yang pertama kali mengembangkan model pembelajaran TAI dengan memadukan kelebihan pembelajaran kooperatif dengan individual. Achdiyat dan Andriyani (2016) mengatakan, model pembelajaran TAI ialah jenis pembelajaran kooperatif yang membentuk kelompok dan di dalamnya terdapat siswa dari kemampuan dan pemahaman yang berbeda agar saling membantu. Slavin (2005) mengemukakan penjelasan bahwa dasar pemikiran model pemebelajaran TAI adalah siswa di dalam 
kelas memiliki berbagai jenis motivasi, kemampuan, dan pengetahuan. Ketika guru memberikan materi pelajaran, kemungkinan beberapa siswa tidak memiliki kemampuan dasar terkait materi yang dibahas dan ada sebagian siswa lainnya mampu mempelajari dengan cepat karena sudah mengetahui materi tersebut.

Fathurrohman (2015) mengatakan bahwa ciri khas pada model pembelajaran ini adalah setiap individu siswa memiliki kemampuan yang berbeda kemudian individu tersebut bersatu dalam keompok kecil guna saling bekerja sama mendiskusikan permasalahan dan seluruh anggota kelompok harus dapat mempertanggungjawabkan solusi yang ditemukan. Dalam model pembelajaran TAI ini, siswa dibentuk menjadi kelompok-kelompok kecil yang dalam kelompok tersebut terdapat 4-5 siswa yang berbeda kemampuannya kemudian diikuti dengan memberikan bantuan individual untuk yang membutuhkannya.

Widodo (2015) menyatakan bahwa model pembelajaran TAI yang merupakan jenis moodel kooperatif dirancang untuk memberikan bantuan individual di dalam kelompok. Dalam penerapannya, siswa diharuskan untuk bekerja sama dalam kelompoknya. Semua anggota kelompok harus dapat mempertanggungjawabkan seluruh jawaban dari latihan yang diberikan. Siswa yang memiliki kemampuan yang memadai bertanggung jawab untuk membantu siswa yang lemah dalam pemahaman dan keterampilannya sehingga siswa yang kurang paham tersebut terbantu dan dapat memahami materi pelajaran. Melalui model pembelajaran ini, Shoimin (2014) mengemukakan bahwa siswa dapat aktif belajar, saling bekerja sama, menyampaikan konsep, gagasan, dan keahlian, memiliki rasa peduli dan tanggung jawab, serta dapat belajar saling menghargai. Disisi lain, Priansa (2017) juga mengatakan bahwa pembelajaran kelompok bertujuan meningkatkan kreatifitas dan kecakapan berpikir kritis, serta menumbuhkan jiwa sosial yang tinggi.

Berikut merupakan langkah-langkah pembelajaran model TAI yang digunakan dalam penelitian ini dan merujuk pada komponen-komponen dalam model TAI yang dikemukakan oleh Slavin (2005).

TABEL 1. Langkah-Langkah Pembelajaran Model TAI

\begin{tabular}{|c|c|c|}
\hline No. & Komponen Pembelajaran TAI & Langkah-Langkah Pembelajaran \\
\hline 1. & Tes Penempatan & $\begin{array}{l}\text { Prosedur pembentukkan kelompok berdasarkan rata-rata } \\
\text { nilai harian sebelumnya guna melihat tingkat kemampuan } \\
\text { siswa. }\end{array}$ \\
\hline 2. & Teams & $\begin{array}{l}\text { Pembentukkan kelompok dimana dalam satu kelompok } \\
\text { tersebut terdapat } 4-5 \text { siswa yang memiliki kemampuan } \\
\text { berbeda-beda atau heterogen, minimal terdapat satu siswa } \\
\text { yang pandai. }\end{array}$ \\
\hline 3. & Teaching Group & $\begin{array}{l}\text { - Guru menyampaikan penjelasan materi pelajaran } \\
\text { dengan singkat menggunakan bantuan media video } \\
\text { interaktif sebelum memberikan tugas untuk } \\
\text { dikerjakan berkelompok. } \\
\text { - Guru memberikan LKS kepada siswa. }\end{array}$ \\
\hline 4. & Student Creative & $\begin{array}{l}\text { - Siswa diberi kesempatan memahami dan membaca } \\
\text { soal yang terdapat pada LKS secara individu. } \\
\text { - Pada tahap ini, guru perlu membangun persepsi } \\
\text { bahwa keberhasilan kelompok menentukan } \\
\text { keberhasilan setiap individu. }\end{array}$ \\
\hline & Team Study & $\begin{array}{l}\text { - Siswa berdiskusi dalam menyelesaikan soal yang } \\
\text { berhubungan dengan pokok bahasan yang sedang } \\
\text { dipelajari yang terdapat pada LKS dengan teman satu } \\
\text { kelompok. } \\
\text { - Guru membantu siswa secara individu apabila siswa } \\
\text { tersebut membutuhkannya. } \\
\text { - Siswa yang memiliki kemampuan optimal dapat } \\
\text { membantu siswa yang berkemampuan lemah. }\end{array}$ \\
\hline
\end{tabular}




\begin{tabular}{|c|c|c|}
\hline No. & Komponen Pembelajaran TAI & Langkah-Langkah Pembelajaran \\
\hline & & $\begin{array}{l}\text { - Siswa mengerjakan tes formatif yang terdapat pada } \\
\text { LKS secara individu kemudian hasil jawabannya } \\
\text { dikoreksi dengan teman lainnya dalam satu kelompok. }\end{array}$ \\
\hline 6. & Whole-Class Unit & $\begin{array}{l}\text { - Perwakilan kelompok memaparkan hasil kerja } \\
\text { kelompoknya dan kelompok yang lain menanggapi. } \\
\text { - Guru dan siswa membuat rangkuman materi dan } \\
\text { refleksi pembelajaran. }\end{array}$ \\
\hline 7. & Fact Test & $\begin{array}{l}\text { Guru memberikan tes-tes kecil berupa soal pemecahan } \\
\text { masalah dan dikerjakan secara individu, seperti kuis } \\
\text { diakhir pembelajaran. }\end{array}$ \\
\hline 8. & $\begin{array}{l}\text { Team Scores and Team } \\
\text { Recognition }\end{array}$ & $\begin{array}{l}\text { Guru menilai hasil kerja tim dengan memberikan skor dan } \\
\text { penetapan penghargaan bagi tim baik, tim hebat, dan tim } \\
\text { super. }\end{array}$ \\
\hline
\end{tabular}

\section{Media Pembelajaran Video Interaktif}

Media dalam pembelajaran berarti perantara atau pengantar yang berguna secara efektif dalam kegiatan pembelajaran yang terencana. Sundayana (2014) mengatakan bahwa media pembelajaran ialah alat atau sejenisnya yang berguna dalam kegiatan pembelajaran sebagai perantara pembawa pesan berupa materi pelajaran yang bertujuan agar siswa mudah mengerti dan memahami pesan tersebut. Dengan demikian, media pembelajaran ialah alat atau sejenisnya yang berguna sebagai perantara dalam proses kegiatan pembelajaran agar dimudahkan dalam memahami dan mengerti informasi atau materi yang diberikan.

Penelitian ini menggunakan media pembelajaran berupa video interaktif. Rosmaya, Sulaeman, \& Purwati (2019) mengatakan bahwa media video interaktif merupakan media yang berupa cerita bergerak dengan disertai suara dan dapat digunakan untuk belajar. Menurut Busyaeri, Udin, dan Zaenudin (2016), video interaktif dapat membantu guru untuk menggambarkan secara nyata berbagai materi yang bersifat abstrak agar siswa dapat memahaminya dengan mudah. Berdasarkan penjelasan yang telah diuraikan, dapat dikatakan bahwa video interaktif adalah media pembelajaran yang mengandung unsur gambar, suara, teks, ataupun grafis yang dapat memudahkan pengguna untuk memahami materi dan di dalamnya terjadi interaksi untuk menghubungkan pengguna dengan media tersebut.

Penggunaan video interaktif dalam pembelajaran jarak jauh dapat memudahkan siswa untuk memahami konsep materi yang diajarkan daripada hanya sekadar membaca. Mahadewi, Ardana, dan Mertasari, (2020) menyatakan bahwa adanya perbedaan kemampuan pemahaman siswa dalam pembelajaran dapat diatasi dengan digunakannya media interaktif berupa video pembelajaran sehingga siswa yang tidak paham dengan hanya membaca dapat terbantu. Dengan demikian, video interaktif dapat membangun pengetahuan dan meningkatkan pemahaman sehingga dapat memudahkan siswa menemukan solusi inspiratif untuk menyelesaikan suatu masalah.

Seiring perkebangan zaman, sudah banyak media dari berbagai macam aplikasi yang dapat dijadikan untuk menampilkan video dan berinteaksi langsung secara virtual dalam pembelajaran jarak jauh, salah satunya adalah Google Meet. Juniartini dan Rasna (2020) mengatakan bahwa Google Meet merupakan sebuah aplikasi yang digunakan antara dua pihak atau lebih yang dapat berinteraksi secara daring melalui pengiriman audio dan video dan dikembangkan oleh Google. Menurut Yuangga \& Sunarsi (2020), aplikasi Google Meet digunakan untuk pertemuan tatap muka secara online agar siswa dapat memperhatikan guru. Dalam aplikasi ini kita dapat berkomunikasi dengan siapapun melalui video. Selain itu, aplikasi Google Meet juga terdapat fitur presentasi yang dapat digunakan untuk menampilkan atau menayangkan video pembelajaran yang dapat memudahkan siswa untuk memahami pelajaran. Aplikasi Google Meet terdapat fitur "hands up" dan kolom chat untuk bertanya dan berinteraksi. 


\section{Pembelajaran Jarak Jauh}

Dewasa ini, Indonesia sedang dilanda wabah coronavirus atau biasa disebut COVID-19. Guna mengurangi penyebaran kasus COVID-19 pemerintah membuat kebijakan PSBB (Pembatasan Sosial Berskala Besar). Salah satu solusi untuk mengatasi kesulitan dengan adanya aturan PSBB adalah diterapkannya proses KBM dari rumah masing-masing dengan menerapkan pembelajaran jarak jauh.

Ahmad (2020) mengatakan bahwa pembelajaran jarak jauh ialah proses kegiatan pembelajaran yang dilangsungkan oleh siswa dan guru secara terpisah, dimana keduanya berada dalam tempat yang berbeda saat pembelajaran tersebut berlangsung. Pembelajaran jarak jauh menurut Kusuma \& Hamidah (2020) adalah proses interaksi antara siswa dan guru pada suatu ruangan yang berbeda (tidak face to face), baik secara langsung melalui chatting atau video konferens maupun tidak langsung melalui email. Disisi lain, Prawiyogi et al., (2020) mengatakan bahwa dalam pelaksaan pembelajaran jarak jauh, materi pelajaran dapat disampaikan tanpa harus melalui tatap muka secara langsung dalam satu ruangan dan didukung dengan penggunaan media agar memungkinkan terjadinya interaksi antara guru dan siswa. Berdasarkan uraian yang disebutkan sebelumnya, dapat dinyatakan bahwa pembelajaran jarak jauh adalah suatu proses interaksi guru dan siswa dalam proses kegiatan pembelajaran dimana mereka berada pada tempat yang berbeda, baik secara langsung (chatting, video konferens) maupun tidak langsung (email) dan pelaksanaannya didukung oleh penggunaan media berbasis internet.

Pembelajaran jarak jauh juga melibatkan media elektronik sebagai sarana dalam penyampaian materi kepada siswa. Pakpahan dan Fitriani (2020) mengemukakan bahwa perlu adanya pemanfaatan teknologi informasi untuk menunjang pelaksanaan PJJ dengan menjalankan perangkat komputer atau gawai yang menghubungkan guru dan siswa. Dalam pengembangannya, kini sudah banyak adanya aplikasi-aplikasi yang dapat dijadikan sebagai media dalam PJJ yang dapat menghubungkan guru dan siswa, diantaranya adalah Whatsapp, Googleclassroom, Zoom meeting, Edmodo, dan lain sebagainya. Kusuma dan Hamidah (2020) mengemukakan bahwa siswa merupakan fokus utama yang diminta untuk lebih inisiatif dan aktif dalam proses kegiatan PJJ. Siswa tidak hanya berfokus pada guru, melainkan dapat mencari referensi dan menggunakan sumber belajar lain yang didapat dari internet. Hal tersebut berarti mengharuskan siswa untuk mandiri dalam proses pembelajarannya.

\section{METODE}

Metode yang digunakan dalam penelitian ini adalah Quasi experimental method atau metode eksperimen semu dengan desain penelitian posttest-only control group design. Populasi terjangkau pada penelitian ini adalah seluruh seluruh siswa kelas VIII SMP Negeri 172 Jakarta yang terdiri dari kelas VIII-1 sampai VIII-8. Cara pengambilan sampel pada penelitian ini dilakukan dengan acak menggunakan teknik two stage sampling. Tahap pertama menggunakan teknik purposive sampling, terpilihlah guru yang mengajar lima kelas yang sama. Tahap kedua menggunakan teknik cluster random sampling, yaitu pengambilan sampel 2 kelas dari 3 kelas yang lolos uji prasyarat analisis data sebelum perlakuan (uji normalitas, uji homogenitas, dan uji kesamaan rata-rata). Terpilihnya kelas VIII-4 (32 siswa) sebagai kelas eksperimen yang mendapat perlakuan berupa pembelajaran dengan model TAI berbantuan video interaktif dan kelas VIII-5 (32 siswa) sebagai kelas kontrol yang mendapat perlakuan berupa pembelajaran konvensional.

Data dikumpulkan dengan teknik tes. Penelitian ini mengguanakan instrumen post-test kemampuan pemecahan masalah matematis. Bahan tes kemampuan pemecahan masalah ini berupa 4 butir soal uraian yang diambil dari materi SPLDV yang telah dinyatakan valid dan reliabel. Hasil akhir perhitungan uji validitas empiris dapat dilihat pada tabel 2 berikut.

TABEL 2. Hasil Uji Validitas Empiris Instrumen Tes

\begin{tabular}{cccccc}
\hline $\begin{array}{c}\text { Butir } \\
\text { Soal }\end{array}$ & $\boldsymbol{r}_{\boldsymbol{x y}}$ & Keterangan & Kesimpulan & Korelasi & Interpretasi \\
\hline $\mathbf{1}$ & 0,653 & $r_{x y}>r_{\text {tabel }}$ & Valid & Sedang & Cukup tepat \\
\hline $\mathbf{2}$ & 0,739 & $r_{x y}>r_{\text {tabel }}$ & Valid & Tinggi & Tepat \\
\hline
\end{tabular}




\begin{tabular}{cccccc}
\hline $\begin{array}{c}\text { Butir } \\
\text { Soal }\end{array}$ & $\boldsymbol{r}_{x y}$ & Keterangan & Kesimpulan & Korelasi & Interpretasi \\
\hline $\mathbf{3}$ & 0,656 & $r_{x y}>r_{\text {tabel }}$ & Valid & Sedang & Cukup tepat \\
\hline $\mathbf{4}$ & 0,773 & $r_{x y}>r_{\text {tabel }}$ & Valid & Tinggi & Tepat \\
\hline
\end{tabular}

Hasil perolehan nilai reliabilitas dari instrumen tes kemampuan pemecahan masalah adalah $r_{11}=$ 0,640 dengan nilai $r_{\text {tabel }}=0,349$. Hal tersebut menunjukkan bahwa $r_{11}>r_{\text {tabel }}$. Dapat dikatakan bahwa instrumen tes pada penelitian ini dapat dipercaya (reliabel) dengan taraf signifikansi $\alpha=0,05$ dan masuk dalam kategori tinggi.

Uji hipotesis statistik dalam penelitian ini menggunakan uji t dengan taraf signifikan $(\alpha=0,05)$ yang sebelumnya terlebih dahulu dilakukan uji normalitas dan uji homogenitas. Rumusan hipotesis statistik pada penelitian ini adalah sebagai berikut:

$H_{0}: \mu_{1} \leq \mu_{2}$

$H_{1}: \mu_{1}>\mu_{2}$

Keterangan :

$H_{0}$ : Hipotesis nol

$H_{1}$ : Hipotesis alternatif

$\mu_{1} \quad$ : Rata-rata hasil tes kemampuan pemecahan masalah matematis siswa kelaseksperimen.

$\mu_{2} \quad$ : Rata-rata hasil tes kemampuan pemecahan masalah matematis siswa kelas kontrol.

Selanjutnya, menentukan besar pengaruh dari penerapan model pembelajaran TAI berbantuan video interaktif dalam pembelajaran jarak jauh terhadap kemampuan pemecahan masalah matematis dengan menggunakan rumus Cohen's effect size (ES).

\section{HASIL DAN PEMBAHASAN}

Pengujian normalitas yang diterapkan dalam penelitian ini ialah uji Lilliefors pada taraf signifikansi 0,05 . Adapun kriteria pengujiannya adalah jika $L_{\text {hitung }}<L_{\text {tabel }}$ maka terima $\mathrm{H}_{0}$ yang berarti data berdistribusi normal. Hasil analisis perhitungan distribusi normal kelas eksperimen didapat hasil $L_{\text {hitung }}$ sebesar 0,061 dan $L_{\text {tabel }}$ sebesar 0,157. Sedangkan, pada kelas kontrol didapat hasil $L_{\text {hitung }}$ sebesar 0,143 dan $L_{\text {tabel }}$ sebesar 0,157. Perolehan akhir perhitungan uji Lilliefors kelas eksperimen dan kelas kontrol dirangkum pada tabel 3.

TABEL 3. Hasil Uji Normalitas Setelah Perlakuan

\begin{tabular}{cccccc}
\hline Kelas & $\boldsymbol{N}$ & $\mathbf{A}$ & $\mathbf{L}_{\text {hitung }}$ & $\mathbf{L}_{\text {tabel }}$ & Kesimpulan \\
\hline Eksperimen & 32 & 0,05 & 0,061 & 0,157 & Berdistribusi Normal \\
\hline Kontrol & 32 & 0,05 & 0,143 & 0,157 & Berdistribusi Normal \\
\hline
\end{tabular}

Jika dibandingkan besar nilai $L_{\text {hitung }}$ dengan nilai $L_{\text {tabel }}$ pada kelas eksperimen dan kelas kontrol maka kedua kelas tersebut memiliki nilai $L_{\text {hitung }}<L_{\text {tabel }}$. Dapat disimpulkan bahwa kelas eksperimen dan kelas kontrol data berdistribusi normal. Kemudian dilakukan uji prasyarat selanjutnnya yaitu uji homogenitas dengan menggunakan uji Fisher. Pengujian ini bertujuan untuk mengetahui kehomogenan varians-vaians dua distribusi atau lebih. Adapun kriteria uji hipotesisnya adalah terima $\mathrm{H}_{0}$ jika $\mathrm{F}_{\text {hitung }}<\mathrm{F}_{\text {tabel }}$ yang artinya variansi kedua kelas homogen atau sama.

TABEL 4. Hasil Uji Homogenitas Sesudah Perlakuan

\begin{tabular}{cccccc}
\hline Kelas & $\boldsymbol{N}$ & Varians & $\mathbf{F}_{\text {hitung }}$ & $\mathbf{F}_{\text {tabel }}$ & Kesimpulan \\
\cline { 1 - 3 } Eksperimen & 32 & 176,541 & \multirow{2}{*}{1,245} & \multirow{2}{*}{1,822} & \multirow{2}{*}{ Homogen } \\
\cline { 1 - 2 } Kontrol & 32 & 219,786 & & & \\
\hline
\end{tabular}


Berdasarkan hasil perhitungan, diperoleh $\mathrm{F}_{\text {hitung }}=1,245$ dan nilai dari $\mathrm{F}_{\text {tabel }}$ pada taraf signifikansi 0,05 sebesar 1,822. Hal tersebut menunjukkan bawah $\mathrm{F}_{\text {hitung }}<\mathrm{F}_{\text {tabel. }}$. Dengan demikian dapat disimpulkan bahwa variansi kedua kelas tersebut homogen.

Berdasarkan hasil pengujian persyaratan analisis data yang meliputi normalitas dan homogenitas diketahui bahwa kedua kelas berdistribusi normal dan memiliki varians yang homogen, sehingga dapat dilanjutkan menggunakan uji uji-t dalam pengujian hipotesis pada penelitian ini.

TABEL 5. Hasil Uji Persamaan Dua Kelas Setelah Perlakuan

\begin{tabular}{cccc}
\hline & Uji-t & & Kesimpulan \\
\hline $\boldsymbol{t}_{\text {hitung }}$ & & $\boldsymbol{t}_{\text {tabel }}$ & Tolak $H_{0}$ \\
\hline $\mathbf{3 , 3 7 6}$ & 1,670 & . \\
\hline
\end{tabular}

Adapun kriteria uji hipotesisnya jika $\mathrm{t}_{\text {hitung }}>\mathrm{t}_{\text {tabel }}$ maka tolak $\mathrm{H}_{0}$. Berdasarkan hasil perhitungan rata-rata kelas eksperimen dengan kelas kontrol diperoleh $t_{\text {hitung }}=3,376$ dan $t_{\text {tabel }}=1,670$. Hal tersebut menunjukkan bahwa nilai $t_{\text {hitung }}>t_{\text {tabel }}$. Dengan demikian, dapat dinyatakan bahwa terdapat pengaruh model pembelajaran TAI berbantuan video interaktif dalam pembelajaran jarak jauh terhadap kemapuan pemecahan masalah matematis siswa.

Dari hasil data pengujian hipotesis menghasilkan tolak $\mathrm{H}_{0}$, yang berarti terdapat pengaruh pengaruh model pembelajaran TAI berbantuan video interaktif dalam pembelajaran jarak jauh terhadap kemapuan pemecahan masalah matematis siswa. Selanjutnya, besar pengaruh tersebut dapat ditentukan dengan menggunakan rumus Cohen's effect size (ES). Hasil perhitungan menunjukkan bahwa nilai ES sebesar 0,844 . Hal tersebut berarti bahwa besar pengaruh yang diberikan dari penerapan model pembelajaran TAI berbantuan video interaktif terhadap kemampuan pemecahan masalah matematis siswa termasuk dalam kategori tinggi.

\section{Pembahasan}

Perolehan hasil pengujian hipotesis statistik memberikan kesimpulan bahwa kelas eksperimen memiliki nilai rata-rata yang lebih tinggi dari kelas kontrol. Hal tersebut disebabkan oleh perbedaan penerapan model pembelajaran yang diberikan selama proses pembelajaran pada masing-maisng kelas. Proses pembelajaran pada kelas eksperimen menerapkan model pembelajaran TAI berbantuan video interaktif. Sedangkan, pada kelas kontrol belajar dengan model pembelajaran konvensional.

Tahap awal pembelajaran, guru membuat beberapa kelompok kecil yang terdapat empat orang siswa dalam satu kelompoknya. Pembentukan kelompok ditentukan berdasarkan nilai UTS semester ganjil 2020/2021. Masing-masing kelompok terdapat siswa yang berbeda kemampuannya atau heterogen, dimana pada satu kelompok tersebut terdiri dari siswa yang memiliki kemampuan tinggi, sedag, dan rendah. Guru memberikan semangat dan motivasi belajar serta menyampaikan tujuan pembelajaran.

Tahap selanjutnya, guru menyampaikan irformasi terkait materi pelajaran secara ggaris besar menjelang pemberian tugas kelompok bantuan media video interaktif melalui Google Meet. Penggunaan media video pembelajaran bertujuan untuk memudahkan siswa dalam menerima dan mengingat informasi serta dapat meningkatkan pemahaman. Pada proses pembelajaran guru pun menyajikan masalah dan mengikutsertakan siswa secara aktif untuk memecahkan masalah tersebut. Partayasa et al., (2020) mengemukakan bahwa penyajian masalah disertai dengan video pembelajaran sebagai pengetahuan awal dapat memberikan manfaat kepada siswa dimana hal tersebut setidaknya dapat memberikan gambaran tentang materi dan landasan berpikir untuk menentukan strategi yang diterapkan dalam menemukan solusi permasalahan. Guru memberikan keleluasaan siswa untuk berpikir melalui tanya jawab.

Guru memberikan permasalahan baru yang disajikan pada Lembar Kerja Peserta Didik (LKPD) yang disusun sesuai indikator kemampuan pemecahan masalah matematis untuk dapat memunculkan kemampuan tersebut. Siswa diberi waktu untuk membaca dan memahami permasalahan di LKPD secara individu. Kemudian, informasi-informasi yang didapat siswa sebelumnya dapat dijadikan bahan 
diskusi melalui WA Group dengan bertukar informasi dan mengungkapkan pendapatnya untuk merencanakan dan menyusun strategi serta merumuskan masalah matematis dalam memecahkankan masalah dan selanjutnya dapat menerapkan strategi tersebut untuk menyelesaikan permasalahan. Siswa yang berkemampuan tinggi bertanggung jawab terhadap siswa yang rendah dalam pemahaman matematika dan keterampilannya sehingga siswa yang lemah terbantu dan dapat memecahkan masalah. Al Ayyubi, Nudin, dan Bernard (2018) menyatakan bahwa pemberian lembar kerja peserta didik berupa masalah untuk didiskusikan secara berkelompok akan memotivasi siswa untuk memiliki rasa ingin tahu sehingga siswa mendapatkan pengetahuan dan pengalaman baru dalam menemukan solusi dari permasalahan tersebut.

Guru pun memberi bantuan seperlunya jika terdapat siswa yang merasa kesulitan dengan cara mengarahkan siswa untuk mengaitkan informasi yang dimiliki dengan materi pelajaran sehingga ditemukan soslusi dari permasalahan tersebut oleh siswa. Selanjutnya, siswa diminta untuk menyelesaikan tes formatif secara individu untuk menumbuh sikap mandiri dan percaya diri bahwa mereka mampu menyelesaikan permasalahan yang kemudian hasil jawaban tersebut dikirim ke WA Group untuk diperiksa kembali oleh teman kelompok yang lain. Dengan mengikutsertakan siswa secara aktif dalam proses KBM maka dapat mengembangkan kemampuan pemecahan masalah matematis siswa.

Tahap berikutnya adalah whole-class unit. Pada tahap ini dilakukan presentasi hasil kerja kelompok oleh perwakilan kelompok melalui media Google Meet. Kelompok yang lain diharapkan untuk memeriksa kembali hasil yang telah dipaparkan oleh kelompok presenter. Jika ada yang kurang, maka siswa diminta untuk menambahkan dan menanggapinya. Hal tersebut dapat mengembangkan pengetahuan untuk menyelesaikan masalah. Mahuda (2017) mengatakan bahwa pembelajaran yang efektif dan bermakna dengan memberi kesempatan kepada siswa untuk berinteraksi terhadap sesama dan lingkungan sosialnya sehingga akan memberikan pengetahuan baru berdasarkan pengalamannya dapat diindikasikan sebagai cara untuk meningkatkan kemampuan pemecahan masalah matematis siswa.

Pembelajaran berbeda dilakukan pada kelas kontrol yang mendapat perlakuan berupa model pembelajaran konvensional. Dalam pembelajaran tersebut, guru tidak menggunakan media pembelajaran video interaktif berbasis Google Meet dan siswa tidak diberikan LKPD untuk didiskusikan bersama. Siswa cenderung kurang aktif karena sebelumnya sudah terbiasa dengan pembelajaran pasif ketika tatap muka di kelas. pada setiap pertemuannya, guru hanya memberikan ringkasan materi beserta contoh soal melalui WA Group. Kemudian, guru meminta siswa untuk memahami dan membaca materi tersebut dan mencatatnya kembali. Kemudian siswa diberi soal latihan oleh guru terkait materi yang dipelajari untuk dikerjakan secara mandiri. Siswa tidak terbiasa memecahkan masalah secara mandiri karena siswa hanya terbiasa mengikuti pengerjaan contoh soal yang guru berikan. Tidak adanya fasilitas yang menunjang komunikasi antarsiswa karena dalam kegiatan pembelajaran semua latihan soal dikerjakan secara mandiri oleh masing-masing siswa dan tidak ada kegiatan berkelompok.

Berdasarkan penjelasan yang diuraikan, maka dapat dikatakan bahwa pembelajaran dengan model Team Assisted Individualization berbantuan video interaktif lebih baik daripada kegiatan pembelajaran konvensional dalam meningkatkan kemampuan pemecahan masalah matematis siswa. Oleh karena itu, penerapan model pembelajaran Team Assisted Individualization berbantuan video interaktif dalam pembelajaran jarak jauh memberikan pengaruh signifikan terhadap kemampuan pemecahan maslaah matematis siswa SMP Negeri 172 Jakarta.

Sejalan dengan penelitian Afrilianto (2019) yang mengemukakan bahwakemampuan pemecahan masalah matematis siswa yang mendapat pembelajaran dengan model TAI lebih baik daripada kelas yang mendapatkan pembelajaran dengan model konvensional. Penelitian ini juga relevan dengan penelitian yang dilakukan Kusuma dan Hamidah (2020) yang menyimpulkan bahwa kelas yang melakukan pembelajaran menggunakan Webinar Zoom lebih baik dan lebih efektiv daripada kelas yang melakukan pembelajaran dengan Whatsapp Group. Dengan siswa mengaitkan langsung apa yang siswa alami dalam kehidupan, siswa akan lebih mudah memahami ilmu terapan yang terakandung dalam matematika. 


\section{PENUTUP}

\section{Kesimpulan}

Penelitian ini menerapkan uji t dua sampel independent dengan variansi yang sama untuk melakukan pengujian hipotesis statistik dengan taraf signifikasi $\alpha=0,05$. Dari hasil pengujian hipotesis statistik diperoleh $t_{\text {hitung }}>t_{\text {tabel }}$, maka tolak $\mathrm{H}_{0}$. Artinya, kelas eksperimen memiliki ratarata hasil kemampuan pemecahan masalah yang lebih tinggi daripada kelas kontrol. Berdasarkan hal itu, dapat disimpulkan bahwa model pembelajaran Teams Assisted Individualization berbantuan video interaktif dalam pembelajaran jarak jauh memberikan pengaruh secara signifikan terhadap kemampuan pemecahan masalah matematis siswa SMP Negeri 172 Jakarta. Penerapan model pembelajaran TAI berbantuan video interaktif terhadap kemampuan pemecahan masalah matematis siswa memberikan pengaruh yang tinggi. Hal tersebut dilihat dari perolehan uji Effect Size yang bernilai ES = 0,844 dengan persentase $79 \%$.

\section{REFERENSI}

Achdiyat, M., \& Andriyani, F. (2016). Hasil Belajar Matematika Ditinjau dari Model Pembelajaran Teams Assisted Individualization (TAI). Formatif: Jurnal Ilmiah Pendidikan MIPA, 6(3). Retrieved from https://journal.lppmunindra.ac.id/index.php/Formatif/article/view/996

Afrilianto, M. (2019). Pengaruh Model Pembelajaran Team Assisted Individualization terhadap Kemampuan Pemecahan Masalah Matematik Siswa SMK. JPMI (Jurnal Pembelajaran Matematika Inovatif), 2(5), 221-228.

Ahmad, I. F. (2020). Asesmen Alternatif dalam Pembelajaran Jarak Jauh pada Masa Darurat Penyebaran Coronavirus Disease (covid-19) di Indonesia. Pedagogik: Jurnal Pendidikan, 7(1), 195-222.

Ahmad Susanto, M. P. (2016). Teori belajar dan pembelajaran di sekolah dasar. Kencana.

Aisyah, N. (2011). Pendekatan Pemecahan Masalah Matematika. Online). Diperoleh Dari Www. Staff. Uny. Ac. Id. Pengembangan Pembelajaran Matematika. Diakses, 20.

Al Ayyubi, I. I., Nudin, E., \& Bernard, M. (2018). Pengaruh Pembelajaran Berbasis Masalah terhadap Kemampuan Pemecahan Masalah Matematis Siswa SMA. JPMI (Jurnal Pembelajaran Matematika Inovatif), 1(3), 355-360.

Bernard, M., Nurmala, N., Mariam, S., \& Rustyani, N. (2018). Analisis Kemampuan Pemecahan Masalah Matematis Siswa SMP Kelas IX Pada Materi Bangun Datar. SJME (Supremum Journal of Mathematics Education), 2(2), 77-83.

Busyaeri, A., Udin, T., \& Zaenudin, A. (2016). Pengaruh Penggunaan Video Pembelajaran terhadap Peningkatan Hasil Belajar Mapel IPA di MIN Kroya Cirebon. Al Ibtida: Jurnal Pendidikan Guru MI, 3(1).

Fathurrohman, M. (2015). Model-model Pembelajaran Inovatif. Yogyakarta: Ar-Ruzz Media.

Hendriana, H., \& Soemarmo, U. (2014). Penilaian Pembelajaran Matematika. Bandung: Refika Aditama.

Inayatusufi, C., El Hakim, L., \& Sari, P. (2020). Peningkatan Kemampuan Pemahaman Konsep Matematis melalui Model Kooperatif Tipe Scramble dengan Pendekatan Kontekstual Pada Materi Segiempat dan Segitiga di Kelas VII. Jurnal Riset Pendidikan Matematika Jakarta, 2(2), 28-37.

Juniartini, N. M. E., \& Rasna, I. W. (2020). Pemanfaatan Aplikasi Google Meet Dalam Keterampilan Menyimak Dan Berbicara Untuk Pembelajaran Bahasa Pada Masa Pandemi COVID-19. Jurnal 
Pendidikan Dan Pembelajaran Bahasa Indonesia, 9(2), 133-141.

Kusuma, J. W., \& Hamidah, H. (2020). Perbandingan Hasil Belajar Matematika Dengan Penggunaan Platform Whatsapp Group dan Webinar Zoom Dalam Pembelajaran Jarak Jauh Pada Masa Pandemik COVID 19. JIPMat, 5(1).

Lestari, K. E., \& Yudhanegara, M. R. (2015). Penelitian Pendidikan Matematika. Bandung: PT Refika Aditama.

Mahadewi, N. K. N., Ardana, I. M., \& Mertasari, N. M. S. (2020). Kemampuan Komunikasi Matematis Melalui Model Reciprocal Teaching Berbantuan Media Interaktif. JNPM (Jurnal Nasional Pendidikan Matematika), 4(2), 338-350.

Mahuda, I. (2017). Pembelajaran Kooperatif Co-Op Co-Op Dengan Pendekatan Open-Ended Untuk Meningkatkan Kemampuan Pemecahan Masalah Matematis Siswa SMA. JPPM (Jurnal Penelitian Dan Pembelajaran Matematika), 10(2).

Pakpahan, R., \& Fitriani, Y. (2020). Analisa Pemanfaatan Teknologi Informasi dalam Pembelajaran Jarak Jauh di Tengah Pandemi Virus Corona Covid-19. Journal of Information System, Applied, Management, Accounting and Research, 4(2), 30-36.

Partayasa, W., Suharta, I. G. P., \& Suparta, I. N. (2020). Pengaruh Model Creative Problem Solving (CPS) Berbantuan Video Pembelajaran Terhadap Kemampuan Pemecahan Masalah Ditinjau Dari Minat. JNPM (Jurnal Nasional Pendidikan Matematika), 4(1), 168-179.

Prawiyogi, A. G., Purwanugraha, A., Fakhry, G., \& Firmansyah, M. (2020). Efektivitas Pembelajaran Jarak Jauh Terhadap Pembelajaran Siswa di SDIT Cendekia Purwakarta. Jurnal Pendidikan Dasar, 11(1), 94-101.

Priansa, D. J. (2017). Pengembangan Strategi dan Model Pembelajaran. Bandung: CV Pustaka Setia.

Purwaningsih, D. (2017). Pengaruh Metode Mind Mapping dan Keterampilan Proses Terhadap Kemampuan Pemecahan Masalah Matematis Mata Kuliah Struktur Aljabar. AKSIOMA: Jurnal Matematika Dan Pendidikan Matematika, 8(1), 1-8.

Rosmaya, I., Sulaeman, S., \& Purwati, N. H. (2019). Pengaruh Video Interaktif dan Media Gambar terhadap Kemampuan Merawat Diri pada Anak Tunagrahita. Journal of Telenursing (JOTING), $1(1), 17-26$.

Setiawan, A. R., \& Mufassaroh, A. Z. (2020). Lembar Kegiatan Siswa untuk Pembelajaran Jarak Jauh Berdasarkan Literasi Saintifik pada Topik Penyakit Coronavirus 2019 (COVID-19).

Shoimin, A. (2014). Model Pembelajaran Inovatif dalam Kurikulum 2013. Yogyakarta: Ar-Ruzz Media.

Slavin, R. E. (2005). Cooperative learning teori, riset dan praktik. Bandung: Nusa Media, 236.

Sumarmo, U. (2005). Pengembangan Berfikir Matematik Tingkat Tinggi Mahasiswa SLTP dan SMU serta Mahamahasiswa Strata Satu (S1) Melalui Berbagai Pendekatan Pembelajaran. Laporan Penelitian Hibah Penelitian Tim Pascasarjana-HTPT Tahun Ketiga. Bandung:Tidak diterbitkan.

Sumarmo, U. (2010). Berpikir Dan Disposisi Matematik: Apa, Mengapa, dan bagaimana dikembangkan pada peserta didik. Bandung: FPMIPA UPI.

Sumartini, T. S. (2016). Peningkatan Kemampuan Pemecahan Masalah Matematis Siswa Melalui Pembelajaran berbasis Masalah. Mosharafa: Jurnal Pendidikan Matematika, 5(2), 148-158.

Sundayana, R. (2014). Media dan Alat Peraga dalam Pembelajaran Matematika. Bandung: Alfabeta.

Sundayana, R. (2016). Kaitan antara Gaya Belajar, Kemandirian Belajar, dan Kemampuan Pemecahan Masalah Siswa SMP dalam Pelajaran Matematika. Mosharafa: Jurnal Pendidikan Matematika, 
$5(2), 75-84$.

Suprika, G. (2014). Pengaruh Penerapan Model Pembelajaran Kooperatif Co-Op Co-Op Dengan Strategi Belajar Aktif Index Card Match (Icm) Terhadap Kemampuan Pemecahan Masalah Matematika Siswa Smp Negeri 23 Pekanbaru. Universitas Islam Negeri Sultan Syarif Kasim Riau.

Widjajanti, D. B. (2009). Kemampuan Pemecahan Masalah Matematis Mahasiswa Calon Guru Matematika: Apa Dan Bagaimana Mengembangkannya. Seminar Nasional Matematika Dan Pendidikan Matematika, 5.

Widodo, S. A. (2015). Keefektivan Team Accelerated Instruction Terhadap Kemampuan Pemecahan Masalah dan Prestasi Belajar Matematika Siswa Kelas VIII. Kreano, Jurnal Matematika KreatifInovatif, 6(2), 127-134.

Yuangga, K. D., \& Sunarsi, D. (2020). Pengembangan Media dan Strategi Pembelajaran untuk Mengatasi Permasalahan Pembelajaran Jarak Jauh di Pandemi COVID-19. JGK (Jurnal Guru Kita), 4(3), 51-58.

Yunata, R. S. (2017). Analisis Kesalahan Siswa Berdasarkan Tingkat Kemmapuan Pemecahan Masalah Bangun Ruang Sisi Datar Melalui Tahapan Polya di SMP PGRI 1 DAU. University of Muhammadiyah Malang. 